\title{
An exploration of the perceived relationship between the level of power of stakeholder groups and their resistance to organisational change
}

\author{
by Adrian van Eeden", Margie Sutherland** \\ and Caren B Scheepers
}

\begin{abstract}
The success of organisational change processes can be significantly enhanced by effectively addressing resistance to change among a range of stakeholders as well as the impact of their resistance. There is, however, limited research on the relationship between stakeholders' level of power and their propensity to resist change in a certain manner. This study therefore explored the interrelationships between stakeholders' perceived level of power and their type of resistance, via face-to-face, in-depth interviews with fifteen professional change agents from three sample groups comprising change consultants, internal human resource managers and internal senior managers, all of whom had led change interventions. The findings revealed surprising trends in that certain stakeholder groups showed resistance more actively and overtly than others in direct proportion to their levels of power. These results culminated in a conceptual framework on stakeholders, power and resistance. This article highlights important implications for managers and change practitioners.
\end{abstract}

Key words: change management, resistance to change, level of power, sources of power, stakeholders

\section{Introduction}

Changing market demands necessitate that organisations continually develop new strategies in order to respond and remain competitive. These transformed corporate strategies usually require a range of interventions, from mere adjustments to extensive radical transformation of internal structures and processes. A variety of stakeholders, both internal and external to the organisation, are regularly impacted by these changes (Ackermann \& Eden 2011; Ireland, Hoskisson \& Hitt 2013; Kotter \& Schlesinger 2008; Kuhn 2008). An organisation therefore requires outstanding competence in change management. Rigby and Bilodeau's (2015:12) study emphasises, for example, that

Mr Adrian van Eeden is an MBA alumnus at the Gordon Institute of Business Science and a Chief Information Officer at the Gordon Institute of Business Science, University of Pretoria

Prof Margie Sutherland is a Full Professor at the Gordon Institute of Business Science, University of Pretoria.

*** Dr Caren B Scheepers is a Senior Lecturer at the Gordon Institute of Business Science, University of Pretoria. 
executives expect to make even more use of the tool "change management" in the future than in the past.

A typical hindrance to effective change management is perceived as resistance to the change by the targets (Thomas \& Hardy 2011). The change management process therefore has to include identification of particular stakeholders and their possible resistance (Olander \& Landin 2005). Predicting and responding to the resistance of various stakeholder groups would therefore enhance the likelihood of change processes being successful. Insight into the level of stakeholders' power (Greenwood \& Van Buren 2010) could thus assist in pre-empting resistance and planning for the likelihood of resistance by certain stakeholders and the impact that it might have on the change processes (Klonek, Lehmann-Willenbrock \& Kauffeld 2014). There is, however, little evidence of research on the nature of the relationship between stakeholders' level of power and their probable means of resisting change. Investigating these relationships is therefore important as understanding them could help leaders and change consultants plan for stakeholder engagement and prioritise certain groups of stakeholders proactively, given their level of power and likely resistance behaviour.

\section{Literature review}

\subsection{Organisational change management}

Cummings and Worley (2015:13) contend that as organisations have become more global and their environments have become more complex and uncertain, "the scale and intricacies of organisational change have increased". Burke (2008:15) emphasises that although there is no singular, all-encompassing theory of organisational change, "open system theory comes the closest". Schein (2010) contends that change has to be perceived as a process. Kurt Lewin's Planned Change Model is possibly the most influential theory in scholarly and practical studies of organisational change. He highlights the open systems concept of information from the external environment that unfreezes the system and creates the need for change.

Contemporary Complexity Theory proponents likewise refer to Lewin's seminal work on the role of informal structures and forces that influence change (Uhl-Bien \& Marion 2009). They also emphasise that "effective organisational change is generated by the insights and influence of many people" (Lichtenstein et al 2006:2). Heifetz and Linsky (2002) in turn emphasise that change in patterns of behaviour from a number of stakeholders is required to meet complex adaptive challenges. It is to this notion of multiple stakeholders that we turn our attention in the next section.

\subsection{Stakeholders' power in change}

Alhazemi, Rees and Hossain (2013) stress the importance of coordination of all stakeholders in a change process. Although stakeholders often represent conflicting needs, Bourne and Walker (2005) caution that these needs must be identified in order to establish effective communication with all parties. The seminal work by Freeman (1984) and, more recently, the works of Freeman and McVea (2001) as well as Aregbeshola and Munamo (2012) depict stakeholders as groups of individuals who are affected by or could influence the achievement of an organisation's objectives. Burke (2007) extends this to include those whose interests are impacted by initiatives either during or after the change process. Newcombe (2010) differentiates between internal and external stakeholders. The vocabulary of "stakeholding" has become commonplace in business (De Bussy \& Kelly 2010). 
Robbins, Judge, Odendaal and Roodt (2009:485) define power as the "capacity that A has to influence the behaviour of B so that B acts in accordance with A's wishes". Raven (2008) defines social power as the potential influence of the agent to bring about a change in belief, attitude or behaviour of the target. Similarly, Willer, Lovaglia and Markovsky (1997) emphasise that power produces influence. Buchanan and Badham (1999:611) refer to political behaviour as the "practical domain of power in action worked out through the techniques of influence...". Rashid (2015) contends that managers must assess the extent of stakeholders' powers to influence the company. Sources of power or power bases have been the topic of significant research (Robbins et al 2009). Gupta and Sharma (2008) distinguish between soft and hard power in their study.

The framework of Greiner and Schein (1988) offers a comprehensive breakdown of power bases that can be applied in practical research on sources of power and was therefore of interest in this study. They built on French and Raven's (1959) seminal bases of power research and also on Kanter's (1980) notion of capacities which provide power, namely access to resources, information and support and the ability to gain cooperation. Greiner and Schein's (1988) classical framework depicts power in three categories, namely positional, individual and departmental power.

Mitchell, Agle and Wood (1997) offer a useful classification of stakeholders along three dimensions, namely possession of power, legitimacy and urgency in taking the initiative. Seven classifications emerged from this framework. For instance, dormant stakeholders have power but do not use it, possibly because they have no interest in the project and are not close to it; whereas discretionary stakeholders have legitimacy but have no urgent claim and choose not to engage with the project, despite the fact that they could. Burke's (2007), Freeman's (1984), Newcombe's (2010) and Mitchell et al's (1997) approaches to analysing stakeholders were used in this study. Scholars such as Olander and Landin (2005) and Ackermann and Eden (2011) emphasise the need for the analysis of stakeholders in terms of the power they have, the interest they show and the predictability of the power they exhibit. In addition to the points emphasised by these scholars, this study investigated the relationship between the stakeholders' levels of power and their resistance to change.

\subsection{Resistance to change}

Early formative studies like Lewin's (1951) highlight the fact that resistance to change can originate from both environmental factors and internal individualised factors. Lewin views resistance as an obstruction that has to be prevented and overcome. In contrast, contemporary theorists such as Thomas and Hardy (2011) and Bareil (2013) emphasise an alternative approach, known as the celebration of resistance, where resistance is welcomed as eliciting novel ideas for change. There is limited empirical evidence in support of this approach. Piderit's (2000) seminal work highlights the multidimensional approach to resistance, i.e. affective, cognitive and behavioural. She also cautions against attribution error in the evaluation of resistance as those in charge tend to blame others. Chermack (2012) in turn contends that resistance to change impacts the implementation of the change. Summers, Humphrey and Ferris (2012) emphasise the increased level of disruption during change processes. Oreg (2006) presents a model of resistance which separates and aligns three common themes, namely antecedents of resistance, forms of resistance and outcomes of resistance to change. $\mathrm{He}$ also reveals that people's disposition to resist change is based on their self-esteem, need for achievement and locus of control. In contrast, Trader-Leigh (2002) 
emphasises factors relating to the organisation, such as that change that alters values and visions of the existing order elicits increased resistance.

Pideritt (2000) provides the concept of contextual resistance, where different aspects of context elicit different responses, an example being the impact power or prestige has on cognitive resistance, whereas threats to job security are likely to lead to emotional reactions. Oreg's (2006) research builds on these findings by revealing strong relationships between trust in management and cognitive resistance, among others. Other researchers like Giangreco and Peccei (2005), Baker (1989), Smollan (2011) and Hultman (1995) contribute examples of forms of resistance, contrasting overt, open resistance with the more covert or subtle forms as well as citing the passive and active categories.

The literature reviewed did not demonstrate a cohesive typology of resistance behaviours. Hultman (1995) provided a specific list and Bovey and Hede (2001) offered a method of assessing responses via the dimensions of overt versus covert and active versus passive behaviour. Table 1 illustrates change resistance behaviour types as identified by Hultman (1995), mapped to the dimensions of action and behaviour as shown by Bovey and Hede (2001). This framework provides a useful structure for this study's exploratory analysis of resistance behaviours.

Table 1

Forms of resistance to change

\begin{tabular}{|c|c|c|}
\hline \multicolumn{2}{|r|}{ Overt } & Covert \\
\hline Active & $\begin{array}{l}\text { Argumentativeness } \\
\text { Appealing to fear } \\
\text { Blaming or accusatory behaviour } \\
\text { Blocking } \\
\text { Intimidation and threats } \\
\text { Manipulation } \\
\text { Outspoken criticism } \\
\text { Ridiculing } \\
\text { Sabotage }\end{array}$ & $\begin{array}{l}\text { Behind-the-scenes criticism } \\
\text { Fault-finding } \\
\text { Rumour-mongering } \\
\text { Selective use or distortion of facts } \\
\text { Undermining }\end{array}$ \\
\hline Passive & $\begin{array}{l}\text { Verbal agreement without follow-through } \\
\text { Failure to implement } \\
\text { Procrastination } \\
\text { Withholding of information, participation } \\
\text { or support }\end{array}$ & $\begin{array}{l}\text { Feigning ignorance } \\
\text { Withdrawal from the change } \\
\text { Avoiding the change } \\
\text { Standing on the side and allowing the change } \\
\text { to fail }\end{array}$ \\
\hline
\end{tabular}

Source: Adapted from Hultman (1995); Bovey \& Hede (2001)

The table depicts lists of examples of resistance, according to two dimensions, i.e. overt vs covert and active vs passive. Fault-finding actions are an example of covert/active behaviour whereas avoiding the required change behaviour is an example of passive/covert resistance.

\subsection{Summary of literature review}

Although the literature contains numerous studies on power and resistance to change, little has been written about the relationship between these key factors in change processes. This is the gap in the literature that this study sought to explore. The research set out to increase understanding of the alignment between stakeholders' categories, their perceived level of power over the change process and the forms of resistance they displayed to the change initiative. The figure below is an illustration of the dimensions investigated in the study. 
Figure 1

Dimensions investigated in the study

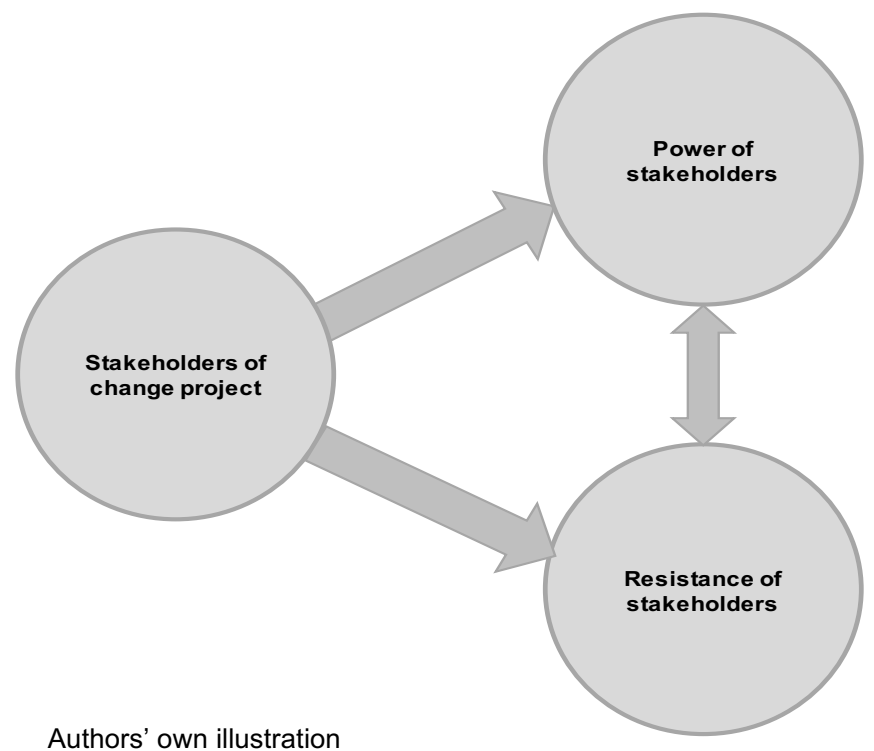

\section{Research objectives}

Three objectives framed the research:

- To explore perceptions on the level of power of stakeholder groups.

- To explore perceptions on levels and forms of resistance in change initiatives.

- To explore perceptions on the relationship between stakeholder groups' levels of power and their forms and levels of resistance.

\section{Methodology}

An exploratory design approach was followed as the research was expected to yield new insights into the interactions between power bases and forms of resistance to change (Saunders \& Lewis 2012). The discussion of power is a sensitive subject, as Greiner and Schein's (1988) seminal work emphasises. In view of the depth of insight required from the research and the sensitivity of the topics, methods of data gathering such as surveys would not have been appropriate; instead an intimate qualitative form of research was required and therefore in-depth interviewing was the method chosen (Gubrium \& Holstein 2001). The relationships between certain constructs in the elicited data were investigated by utilising quantitative structures and statistical testing.

\subsection{Research participants}

The research was conducted on a population of experts from three areas known to drive change, namely external change experts like change consultants, internal organisational design and human capital management consultants and internal technical managers such as business strategists and information technology and process managers who had driven change processes. Fifteen experts were interviewed from different projects and organisations. To minimise maturation effects, projects were 
selected which were recent (not more than five years prior to commencement of the research). The study utilised purposive sampling, which is a non-probability quota sample selection technique (Saunders \& Lewis 2012; Zikmund, Babin, Carr \& Griffin 2013). The experts chosen followed set criteria, such as the experts' involvement in change initiatives and the types of change initiatives they were involved in. Change initiatives varied across scope, duration, impact and cost, but resistance was observed in each initiative. Quota sampling of five experts per population type was used to ensure that there was adequate representation of each group. The three groups are explained in the table below:

Table 2

Quota sample design

\begin{tabular}{|l|l|c|}
\hline \multicolumn{1}{|c|}{ Sample source } & \multicolumn{1}{|c|}{ Examples } & Sample size \\
\hline \multirow{2}{*}{ External change specialists } & $\begin{array}{l}\text { - Change management consultants } \\
\text { - Project managers }\end{array}$ & 5 \\
\hline $\begin{array}{l}\text { Internal drivers of change } \\
\text { (human capital focus) }\end{array}$ & $\begin{array}{l}\text { - OD consultants } \\
\text { - OD man resource management }\end{array}$ & 5 \\
\hline $\begin{array}{l}\text { Internal drivers of change } \\
\text { (technical focus) }\end{array}$ & $\begin{array}{l}\text { - Training and development } \\
\text { - IT management }\end{array}$ & \\
\hline
\end{tabular}

The unit of analysis was the perceptions of these experts who managed change. In qualitative research, sample sizes of 15 are commonly regarded as sufficient (Saunders \& Lewis 2012; Zikmund et al 2013).

\subsection{Data collection method and tools}

The face-to-face, semi-structured, in-depth interviews with experts each lasted an hour on average. This allowed the interviewer to address the topics of power and resistance sensitively and allowed time for the interviewer to probe for more data (Gubrium \& Holstein 2001). An interview guideline was designed around the major themes. Prompt cards showing a five-point scale of levels of power were developed by the researchers to assist the interviewer in determining the perceived level of power of each stakeholder group. The scale is shown in Table 4. However, the use of formal frameworks in the interviews was limited to ensure that the respondents' discussion was based on their own experience and assessment. Two pilot interviews were undertaken to assess the duration of the interview and to refine the data collection method. Changes were made to the data collection sheets and to the flow of the interview guidelines.

\subsection{Data analysis}

All interviews were subject to an initial inductive process of qualitative analysis. Data content analysis was undertaken directly from the interview recordings, extracting key themes based on the frameworks of Mitchell et al (1997), Bovey and Hede (2001) and Burke (2007). These data were then codified and aggregated into digital format. Analyses determined common patterns across all interviews and the themes were transformed into workable data in the form of ranked-order tables and contingency tables which assessed frequency of occurrence and the way variables related to each other. Pearson's chi-square tests were used when testing the independence of two 
nominal-scale variables (Weiers 2011). An Exact test allowed the researchers to perform the same statistical test with a small number of case variables and with expected cell counts below five (IBM 2011). In some cases the Monte Carlo Estimate method was used (Mehta \& Patel 2011).

\subsection{Research limitations}

History and maturation effects might have been present in some cases. Covert resistance is hard to observe and this could have influenced the respondents' perception of whether it was present, so that it may have been underreported. For each change intervention only one person's view was obtained and this may have been a biased view of what actually occurred.

\section{Findings}

\subsection{Stakeholders}

The interviewees did not express a common view on a definition of stakeholders of change initiatives. One interviewee said "that depends on your definition of stakeholder ... our definition would be a decision-maker". Others, in particular consultants, acknowledged broader stakeholder roles. A change consultant said "...we had to manage suppliers, this was a consolidation exercise and different suppliers would bring stuff in at different periods", and an organisational design consultant stated that "I got the union on-board quite early."

Interviewees mentioned an average of eight stakeholder groups each and ten stakeholder groups were decided on after content analysis. The stakeholder groups were then categorised according to Freeman's (1984) concept of stakeholders that were affected by the project or could affect and influence the project and then according to whether they were internal or external to the organisation (Newcombe 2010). This resulted in the ten stakeholder groups being classified into four stakeholder types: internal/can affect groups included directors and executive management, line management, project teams and sponsors. The internal/affected groups were represented by staff. The external/affected stakeholder groups were represented by customers and suppliers. Finally, external/can affect groups were represented by government, shareholders and staff representatives like unions. Given these categories, a contingency table for the data for numbers of types of stakeholders mentioned by the interviewees is given as Table 3 .

Table 3

Stakeholder group relationship matrix

\begin{tabular}{|c|c|c|c|c|}
\hline \multirow{5}{*}{ 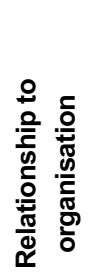 } & & \multicolumn{2}{|c|}{ Relationship to project } & \\
\hline & \multirow{4}{*}{$\begin{array}{l}\text { Internal } \\
\text { External }\end{array}$} & Affected & Can affect & \multirow{3}{*}{$\begin{array}{l}84 \\
36\end{array}$} \\
\hline & & 22 & 62 & \\
\hline & & 19 & 17 & \\
\hline & & 41 & 79 & 120 \\
\hline
\end{tabular}


A Pearson 2-tailed Chi-square test was performed on the data using the asymptotic estimation method. The test value was 7.92 with a $p$ value of 0,005 , indicating that the stakeholder group relationship to the organisation and their relationship to the project (affect or affected) were dependent on each other. Internal stakeholders were found to be able to affect change disproportionately and external stakeholders to be more affected by the change.

\subsection{Which levels of power did each stakeholder group have?}

Our investigation into the research question on levels of power revealed that opinions expressed during the interviews on levels of power varied. One of the projects was referred to as a "top-down autocratic project that nobody was going to criticise", and in another the "executive committee had minimal influence." As discussed above, a prompt card bearing a five-point ordinal scale was shown to the interviewees to gather data on the stakeholders' perceived level of power during the in-depth interviews. The scale shown in Table 4 was created, based on the project management triple constraint model of scope, budget and schedule (Burke 2007).

Table 4

Levels of power over change project

\begin{tabular}{|c|l|}
\hline Level & \multicolumn{1}{c|}{ Description } \\
\hline 1 & Had no influence over the project. \\
\hline 2 & $\begin{array}{l}\text { Had minor influence over the project but would not have been able to cause major impact - } \\
\text { e.g. couldn't through influence cause a material change to the resourcing, scope or timing. }\end{array}$ \\
\hline 3 & $\begin{array}{l}\text { Could influence the initiative in a way that might affect the budget or timing, but the initiative } \\
\text { could still be achieved within the boundaries laid out with adjustment (e.g. more budget, } \\
\text { change of schedule). }\end{array}$ \\
\hline 4 & $\begin{array}{l}\text { Could have a major impact on the direction of the change (i.e. the scope of the project, } \\
\text { duration etc), such as being able to force a change to the scope of the initiative from the } \\
\text { original plan, or significantly affect the desired outcomes (e.g. required returns). }\end{array}$ \\
\hline 5 & $\begin{array}{l}\text { Through their influence, could cause the project to fail outright (e.g. to be cancelled, or } \\
\text { cause the withholding of critical resources). }\end{array}$ \\
\hline
\end{tabular}

The level of power that the stakeholder groups held over a project was distributed as shown in Table 5 below. Modal categories of power for each stakeholder group are highlighted in grey.

Table 5

Levels of power identified by stakeholder group

\begin{tabular}{|l|c|c|c|c|c|c|}
\hline \multirow{2}{*}{\multicolumn{1}{|c|}{ Stakeholder group }} & \multicolumn{9}{c|}{ Level of power } & \multirow{2}{*}{ Total } \\
\cline { 2 - 6 } & $\mathbf{1}$ & $\mathbf{2}$ & $\mathbf{3}$ & $\mathbf{4}$ & $\mathbf{5}$ & 22 \\
\hline Staff & 3 & 8 & 4 & 4 & 3 & 22 \\
Directors and executive management & 1 & 1 & 4 & 5 & 11 & 22 \\
Line / operational management & 2 & 4 & 9 & 3 & 4 & 22 \\
Project team & 1 & 2 & 2 & 5 & 1 & 11 \\
Shareholders & 0 & 1 & 0 & 4 & 5 & 10 \\
Customers & 6 & 0 & 3 & 1 & 0 & 10 \\
Suppliers (upstream) & 5 & 1 & 2 & 1 & 0 & 9 \\
Sponsors & 0 & 0 & 0 & 2 & 5 & 7 \\
Staff representatives (unions) & 0 & 1 & 0 & 2 & 1 & 4 \\
Government / regulation & 1 & 0 & 0 & 0 & 2 & 3 \\
\hline
\end{tabular}


The relationship between the types of stakeholder and their levels of power were investigated. Table 6 reports on the relationship between level of power and whether the stakeholder groups were internal or external to the organisation. The modal frequencies are highlighted by row.

\section{Table 6}

\section{Relationship to organisation and levels of power}

\begin{tabular}{|c|c|c|c|c|c|c|}
\hline \multirow{2}{*}{$\begin{array}{c}\text { Relationship to } \\
\text { organisation }\end{array}$} & \multicolumn{5}{|c|}{ Level of power } & \multirow{2}{*}{ Totals } \\
\hline & 1 & 2 & 3 & 4 & 5 & \\
\hline Internal & 7 & 15 & 19 & 19 & 24 & 84 \\
\hline External & 12 & 3 & 5 & 8 & 8 & 36 \\
\hline Totals & 19 & 18 & 24 & 27 & 32 & 120 \\
\hline
\end{tabular}

A two-tailed p-value Pearson Chi-square test was applied to the data. The Pearson Chi-square value was 12.814 , and the $p$ value of 0.011 was lower than the significance level of 0.05 , showing a significant dependency between stakeholder group relationships to an organisation and the level of power they had over the change initiative. Stakeholder groups internal to the organisation had significantly higher levels of power than those outside the organisation.

The relationship between whether the groups could affect or were affected by the change and their levels of power are shown in Table 7.

Table 7

Relationship to change project and levels of power

\begin{tabular}{|c|c|c|c|c|c|c|}
\hline \multirow{2}{*}{ Relationship to project } & \multicolumn{5}{|c|}{ Level of power } & \multirow{2}{*}{ Totals } \\
\hline & 1 & 2 & 3 & 4 & 5 & \\
\hline Affected & 14 & 9 & 9 & 6 & 3 & 41 \\
\hline Can affect & 5 & 9 & 15 & 21 & 29 & 79 \\
\hline Totals & 19 & 18 & 24 & 27 & 32 & 120 \\
\hline
\end{tabular}

A two-tailed $p$-value Pearson Chi-square test was applied to the data. The Pearson Chi-square value was 25.773 and the $p$ value of zero was lower than the significance level of 0.05 . There was a significant dependency between stakeholder group relationships to projects and the level of power the stakeholders had. Affected groups had much less power than the groups affecting the change.

\subsection{Which forms of resistance were observed in the change initiatives?}

Our exploration of the research objective around forms of resistance indicated that 88 instances of resistant behaviour were observed across the projects and stakeholders. Every instance of resistant behaviour was subcategorised by Bovey and Hede's (2001) framework, as explained in Table 1. The instances of resistance were also divided into subcategories; for example, direct union action in the form of strikes was identified as a "blocking" subcategory; not doing what was required was categorised as "failure to implement". Table 8 below displays the frequencies of each subcategory, and summarises the resistance under the four categories of active-overt, passive-covert, active-covert, and passive-overt, ranked in order of frequency. 
Table 8

Frequencies of observations of resistance

\begin{tabular}{|c|c|c|}
\hline Type of behaviour & Subcategory & Frequency \\
\hline Active Overt & & 36 \\
\hline Outspoken criticism; expression of concern; cynical responses & Outspoken criticism & 12 \\
\hline Arguing; opposition at board; disagreement with strategy & Argumentativeness & 10 \\
\hline $\begin{array}{l}\text { Strike action; refusal to support; withdrawal of support; not doing } \\
\text { their duties (JDs); physical freezing of project; disinvestment; } \\
\text { overriding decisions }\end{array}$ & Blocking & 7 \\
\hline $\begin{array}{l}\text { Hiring against policy; dumping fuel; providing wrong data; } \\
\text { poaching customers; leaving supplier; provision of incorrect data }\end{array}$ & Sabotage & 5 \\
\hline Aggression & Intimidation & 1 \\
\hline Walked out & Resignation & 1 \\
\hline Passive Covert & & 23 \\
\hline $\begin{array}{l}\text { Nonparticipation; withdrawal; avoiding getting involved; not } \\
\text { doing the work; disinterest }\end{array}$ & Avoidance & 16 \\
\hline Watching from the side; waiting to see what will happen & Side-line & 4 \\
\hline Disregarding information; ignoring & Feigning ignorance & 3 \\
\hline Active Covert & & 18 \\
\hline Criticism behind the scenes & $\begin{array}{l}\text { Behind the scenes } \\
\text { criticism }\end{array}$ & 13 \\
\hline Political behaviour/criticism & Undermining & 3 \\
\hline $\begin{array}{l}\text { Blaming and escalating to internal board; providing poor service } \\
\text { to customers }\end{array}$ & Undermining & 2 \\
\hline Passive Overt & & 11 \\
\hline $\begin{array}{l}\text { Not sending specialists to attend sessions; withholding support; } \\
\text { withholding supply of funds; unable to support due to capacity } \\
\text { constraints }\end{array}$ & Withholding & 7 \\
\hline Delay in implementation; dragging feet & Procrastination & 3 \\
\hline Did not do required activities & Failure to Implement & 1 \\
\hline \multicolumn{2}{|l|}{ Totals } & 88 \\
\hline
\end{tabular}

The occurrence of types of resistance behaviour was then examined for dependence in a cross-tabulation, as shown in Table 9.

Table 9

Frequency of resistance observed

\begin{tabular}{|c|c|c|c|}
\hline \multirow{4}{*}{$\begin{array}{c}\text { Active } \\
\text { Passive }\end{array}$} & Overt & Covert & \multirow{4}{*}{$\begin{array}{r}54 \\
34 \\
88\end{array}$} \\
\hline & 36 & 18 & \\
\hline & 11 & 23 & \\
\hline & 47 & 41 & \\
\hline
\end{tabular}

Source: Bovey and Hede (2001)

A Chi-square test of independence was performed on the variables using a standard 2-tailed $p$ value Pearson Chi-square test. The test value was 9.872 and the $p$ value of 0.002 was lower than the significance of 0.05 . The two variables were dependent on each other, with a disproportionate amount of active/overt and passive/covert resistant behaviours. However, the data show that these terms cannot be used interchangeably. 
Table 10 shows the types of resistance to change actions that were observed for each stakeholder group.

Table 10

Resistance actions by stakeholder groups

\begin{tabular}{|l|c|r|r|}
\hline \multirow{2}{*}{ Stakeholder groups } & \multicolumn{2}{c|}{ Action } & \multirow{2}{*}{ Totals } \\
\cline { 2 - 3 } & Passive & Active & \\
\hline Line / Operational management & 15 & 10 & 25 \\
Directors and executive management & 5 & 17 & 22 \\
Staff & 8 & 8 & 16 \\
Shareholders & 1 & 5 & 6 \\
Project team & 4 & 1 & 5 \\
Staff representatives (unions) & 0 & 5 & 5 \\
Suppliers (upstream) & 1 & 2 & 3 \\
Sponsors & 0 & 3 & 3 \\
Customers & 0 & 2 & 2 \\
Government / regulation & 0 & 1 & 1 \\
\hline Total & $\mathbf{3 4}$ & $\mathbf{5 4}$ & $\mathbf{8 8}$ \\
\hline
\end{tabular}

The table clearly shows that line managers and executives exhibited more resistance to change, both active and passive (45 in total), than the other 8 groups combined (41 in total).

To determine whether there was a relationship between the type of stakeholder group and their type of resistance to change, the data were cross-tabulated into Table 11.

Table 11

Relationship matrix of resistance actions by stakeholder groups

\begin{tabular}{|l|r|r|c|}
\hline \multirow{2}{*}{ Stakeholder groups } & \multicolumn{2}{|c|}{ Action } & \multirow{2}{*}{ Totals } \\
\cline { 2 - 3 } & Passive & Active & \\
\hline Internal (can affect) & 24 & 31 & 55 \\
Internal (affected) & 8 & 8 & 16 \\
External (can affect) & 1 & 11 & 12 \\
External (affected) & 1 & 4 & 5 \\
\hline Total & $\mathbf{3 4}$ & $\mathbf{5 4}$ & $\mathbf{8 8}$ \\
\hline
\end{tabular}

The value of the Pearson Chi-square was 6.832 and the $p$ value was 0.073 , which is greater than the significance level of 0.05 and an indication of independence of the variables, i.e. there is no relationship between the type of stakeholder group and the type of resistance behaviour exhibited.

\subsection{Was there a relationship between stakeholder groups' levels and sources of power and their forms of resistance?}

In exploring the research objective around the relationship between stakeholder groups' levels of power and forms of resistance, the interviewees were asked whether each stakeholder group they mentioned had exhibited resistance to change. Many interviewees stated that some of the stakeholders they had mentioned did not resist change. The research then tested whether the level of power each stakeholder group had over the change process bore any relationship to whether or not resistance had been observed. The frequencies of occurrence of resistance are shown in Table 12. 
Table 12

Level of power by occurrence of resistance

\begin{tabular}{|l|r|r|c|}
\hline \multirow{2}{*}{ Power } & \multicolumn{2}{|c|}{ Resistance } & \multirow{2}{*}{ Totals } \\
\cline { 2 - 3 } & Yes & No & \\
\hline 5 (high) & 21 & 11 & 32 \\
4 & 14 & 13 & 27 \\
3 & 14 & 10 & 24 \\
2 & 11 & 7 & 18 \\
1 (low) & 4 & 15 & 19 \\
\hline Totals & $\mathbf{6 4}$ & $\mathbf{5 6}$ & $\mathbf{1 2 0}$ \\
\hline
\end{tabular}

A 2-tailed Pearson chi-square test was performed on this data using an asymptotic estimation method. The Pearson Chi-square value was 10.600 , with a $p$ value of 0.031 . The $p$-value of 0.031 was below the significance of 0.05 , indicating dependency between the level of power and the occurrence of resistance. In a surprising, important finding it appeared that the groups who had higher power over the project demonstrated far higher resistance to change behaviour than those with low power over the change initiative.

For the 64 instances where resistance was observed, the data were analysed to see whether there was a relationship between the level of power and the resistance displayed, either active or passive.

Table 13

Level of power and action

\begin{tabular}{|l|c|c|c|}
\hline \multicolumn{1}{|c|}{ Power } & Active & Passive & Totals \\
\hline 5 (high) & 13 & 8 & $\mathbf{2 1}$ \\
4 & 7 & 7 & 14 \\
3 & 11 & 3 & 14 \\
2 & 1 & 10 & 11 \\
1 (low) & 1 & 3 & 4 \\
\hline Totals & 33 & 31 & $\mathbf{6 4}$ \\
\hline
\end{tabular}

A large number of the cells contained expected counts of less than 5 , so a 2-sided Chisquare test was used. The Pearson Chi-square value was 14.077 and the $p$ value from the Exact test was 0.005 , which is lower than 0.05 , indicating that the variables were dependent on each other, i.e. the stakeholders with higher power exhibited more active forms of resistance while those with lower power demonstrated more passive forms of resistance.

Similarly, the data on overt versus covert resistance were examined by level of power.

Table 14

Relationship between level of power and resistance

\begin{tabular}{|l|c|c|c|}
\hline \multicolumn{1}{|c|}{ Power } & Covert & Overt & Totals \\
\hline 5 (high) & 6 & 15 & $\mathbf{2 1}$ \\
4 & 2 & 12 & $\mathbf{1 4}$ \\
3 & 3 & 11 & $\mathbf{1 4}$ \\
2 & 6 & 5 & $\mathbf{1 1}$ \\
1 (low) & 2 & 2 & $\mathbf{4}$ \\
\hline Totals & $\mathbf{1 9}$ & $\mathbf{4 5}$ & $\mathbf{6 4}$ \\
\hline
\end{tabular}

The Exact method on a 2-sided Chi-square test was used and the value was 6.108, with a $p$ value of 0.190 , which was greater than 0.05 . The two variables, power and overt versus covert resistance, were independent of each other. 


\section{Discussion}

In the interesting findings of this study, some propositions of the current literature were supported and some were contradicted.

\subsection{Stakeholder groups}

As Bourne and Walker (2005) emphasised, stakeholders have to be identified with their respective needs to construct effective communication with them. The study found that ten different stakeholder groups are involved in change processes and the largest three groups identified were staff, line management, and directors, comprising $55 \%$ of the mentions. The lowest group occurrences were unions and government. Even though Freeman (1984), Reed (2008) and Newcombe (2010) alert researchers to the fact that stakeholders are not only internal, by far the greatest occurrence in this study was within the organisation. The potential to have an impact on a project is defined as power by Kanter (1980). In this study the highest proportion $(66 \%)$ of stakeholder groups were seen to be able to affect a project rather than to be affected by it, i.e. to have reasonable levels of power. Our study revealed that internal stakeholders had a higher likelihood $(52 \%)$ of being able to affect a project than external stakeholders. Interestingly, the three sample groups identified stakeholder groups differently. For instance, human resource practitioners had a greater tendency to identify internally aligned stakeholders $(80 \%$ of the time).

\subsection{Levels of power}

The study explored the distribution of types and levels of power of the stakeholder groups during the change processes; the perceptions of interviewees were identified and analysed. Interview data revealed that internal stakeholders had been perceived as having higher degrees of power and the stakeholders most affected by the changes as having the lowest levels of power. The finding of high levels of power seems to contrast with Pfeffer's (1992) view that only the highest levels of management can get things accomplished. Kanter (1980) defines power as the ability to mobilise resources and get things done. Six of the 15 projects considered were driven from the top, either by the CEO or by an executive committee. An interviewee referred to there being a place for the "thou shalt do it" approach to change.

Certain groups were perceived by the interviewees as having very strong relationships with specific levels of power. Directors and executive management, shareholders and sponsors demonstrated high concentrations of level 5 power and in almost all cases fell within the power dimension of Mitchell et al's stakeholder typologies (1997) as either dormant, dominant or definitive, supporting the idea of concentration of power within certain groups. Internal groups that could affect the project were the most frequently recorded powerful groups, holding $61 \%$ of all power observed above a level 3 . This trend supports the findings of Robbins et al (2009), who emphasise that strength of power is about how severe the consequences are and in current organisational structures management would normally have the most control over consequences such as dismissal (coercive power) and promotion (reward power) as per the seminal work of French and Raven (1959).

The study revealed that there was a significant relationship between stakeholder groups and perceptions of their levels of power. There was also dependency between group relationships with the organisation and levels of power. For example, groups with internal relationships with the organisation showed higher levels of power. The implications of these outcomes are that certain types of stakeholder groups may have predictable levels of power which need to be harnessed during change processes. 


\subsection{Resistance to change}

Most of the literature on resistance focuses on why resistance happens, with less focus on the actual manifestations of resistance. Out of the 120 stakeholder groups identified by the interviewees, just over half (64) were observed to display resistance. This was quite surprising as it showed that a significantly large portion of key groups associated with a project were not wholly on board with the change process. The research identified a wide variety of resistant behaviours which could be categorised into the systems mentioned in the literature (Bovey \& Hede 2001; Hultman 1995). The most frequently observed types of resistance included criticism (both outspoken and covert), argumentativeness, avoidance or non-participation, and withholding of resources. Our findings showed that a significantly higher level of resistance was active $(61 \%)$ rather than passive.

The two variables, namely active/passive and overt/covert, were dependent, as expected. The most notable finding was that active-overt resistance made up the highest grouping ( $41 \%$ of observations) and passive-covert $(26 \%)$ the second highest. However, all permutations of these variables were noted and change practitioners should heed passive/overt and active/covert forms. The study indicated that external affected stakeholder groups were more likely not to resist, and internal affected groups were more prone to resist. Some of the examples from the interviews included a chairman who was highly resistant to a strategic project; however in other projects CEOs were the active drivers of the projects. The highest frequencies of resistance action, both active and passive, were observed with internally related stakeholders. However, directors and executive management, shareholders and sponsors were more active in their resistance, whereas line managers were twice as likely to resist in passive ways, which supports the findings of Giangreco and Peccei (2005) and Kanter (1980).

Covert resistant behaviour was possibly underreported as being covert. Such behaviour is less obvious than overt behaviour and change experts might not have observed sufficient instances of covert behaviour when it was present. Findings indicated far higher frequencies of both overt and covert intentional behaviour for internal stakeholder groups, but this could also be related to the low frequencies of external stakeholders being identified in the interviews.

\subsection{Relationship between levels of power and resistance}

An important finding in this research is the establishment of the direct relationship between resistance behaviours and the level of power the stakeholder groups have over the project. Although Trader-Leigh (2002) discussed the impact of change on power coalitions and the status quo, and the redistribution factor where parties lose control, funds, or resources, and Kanter (1980) observed that people affected by projects would use politics and their sources of power to direct their resistance, this is the first documentation of the nature of this relationship.

The most interesting and unexpected finding was that stakeholders perceived as having the highest levels of power were the most likely to display resistance. For instance, $66 \%$ of the stakeholders deemed to have level 5 power demonstrated resistance, whereas only $21 \%$ of stakeholders having level 1 power resisted in any way. The study therefore confirmed that level of power and resistance showed positive interdependence. Furthermore, resistance is more likely to take an active form when power levels are high, and a passive one when power levels are low. This supports some of the ideas of Piderit (2000) and Oreg (2006). Our study also supported Kanter's (1980) notion that power and resistance are related but this was not empirically tested previously. 
The research reinforces literature findings which indicate that organisational structures create power bases. People resist changes to the nature of their power, and power enables people to cause harm in a greater or lesser degree. External stakeholders and staff that were most affected by the change project had the lowest levels of power, which of course would make them the most vulnerable. The work of Greenwood and Van Buren (2010) on trustworthiness of organisations is relevant here. Change project leaders must take note of the ethical issues in stakeholder relationships and endeavour to treat all stakeholders fairly, even those with low power and those who display less active resistance.

\subsection{Implications for practitioners}

Our research focused on three broad themes, namely stakeholder groups, power and resistance; and more specifically on how these relate to each other across a change initiative. The research offered two novel frameworks for practitioners, namely the framework for cataloguing types of resistance by using the four combinations of active/passive and covert/overt and the framework for depicting levels of power on change projects using descriptions in project management language. These frameworks could be utilised by practitioners on change projects to differentiate and categorise the types of resistance that they encounter as well as estimate the level of power that their stakeholder groups display. These frameworks could then be used in proactive planning to move projects forward. Tables 4 and 8 , which show the internal/external and affect/affected by categories and types of resistance that could be encountered, are also important for practitioners. They could utilise the insights provided to differentiate between stakeholder groups. As Olander and Landin (2005) stressed, this is a necessary step in planning change projects.

Surprising relationships were uncovered, and an integrating model was developed to graphically collate the findings.

\section{Figure 2}

Stakeholders' power and resistance model

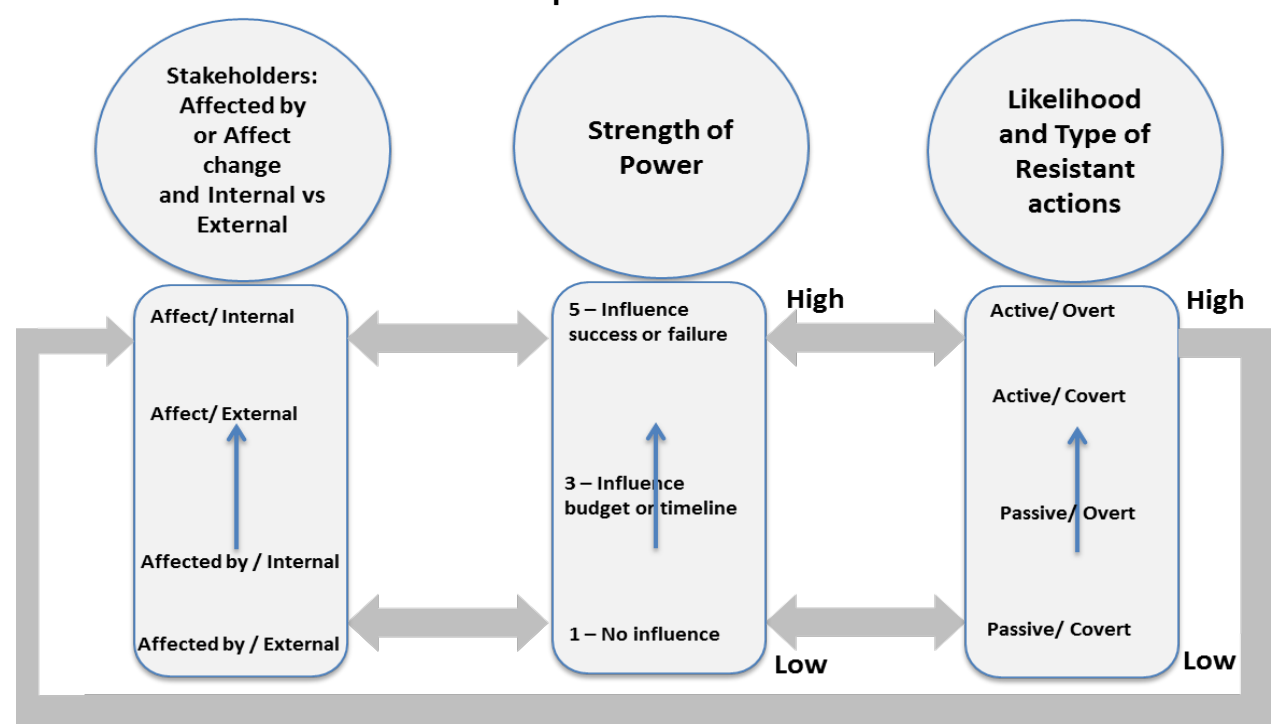

Authors' own illustration 
The model in Figure 2 depicts the significant finding in our research that the higher the level of power the more active and overt the resistance will be and the higher the likelihood that resistant actions will take place. The stakeholder groups that were more likely to have high power were those with an internal relationship with the organisation and the ability to affect the change project, such as directors and executives or line and operational management. Figure 2 shows that these stakeholders' likelihood of affecting the change project could increase, owing to their high levels of power and subsequent high levels of resistance. Change projects would therefore need to accommodate the concerns of and criticism from these important stakeholders. Once their issues have been addressed, their access to support as a power source could assist project progress. Of further interest is the finding that staff who had lower levels of power reverted to moderate active and passive resistance, whereas customers who had low levels of power were less likely to show resistance. A particular concern is the project team who had higher power or influence on the project, but often reverted to passive resistance, which included procrastinating and feigning ignorance. The success of a change initiative can obviously be hugely negatively impacted by these actions.

These implications could be fruitfully utilised in a change planning process by considering stakeholders on a project in a structured manner and predicting their behaviour, so that a mitigation or response strategy could be prepared. If groups are not expected to resist, then planning could involve finding ways to lobby support and continue to keep these people engaged and positive. If groups are expected to resist, the model can predict the type of resistance and form either a contingency strategy to reduce the likelihood of the behaviour occurring, or respond to it when it does with a mitigation plan to reduce the impact. For example, if active, overt resistance is expected from a senior internal stakeholder group, then perhaps their sources of power could be adjusted to change their behaviour. A group could have their legitimacy consciously removed (for example through demotion or transfer) or training could be guided towards diluting a particular group's knowledge power by empowering more people in the organisation.

\subsection{Recommendations for future research}

A further study on the same topic from the viewpoint of non-managerial staff may yield interesting findings. Seeing that there was a possible limitation in the observation of covert behaviour, a more sensitive and directed approach to collecting data on covert behaviour would probably reveal important findings. Future studies could investigate specific resistance response activities, e.g. overt/passive activities, and how best they should be responded to. Further research on various aspects of the model in Figure 2 would strengthen understanding of the relationship between the dimensions and extend the ability to plan for resistance to change.

This research clearly contributes to understanding the relationship between stakeholders, their power and resistance to change and could provide valuable inputs into systematic change planning processes by addressing the revealed resistance of high power stakeholder groups.

\section{List of references}

Ackerman, F \& Eden, C. 2011.Strategic management of stakeholders: Theory and practice. Long Range Planning 44:179-196. 
Alhazemi, AA, Rees, C \& Hossain, F. 2013. Implementation of strategic organizational change: The case of King Abdul Aziz University in Saudi Arabia. International Journal of Public Administration 36(13):972-981.

Aregbeshola, AR \& Munamo, EM. 2012. The relationship between stakeholders' involvement in strategic planning and organisation's performance - A study of the University of Venda. International Business \& Economics Research Journal 11(11):1175-1190.

Baker, SL. 1989. Managing resistance to change. Library Trends 38(1):53-61.

Bareil, C. 2013. Two paradigms about resistance to change. Organizational Development Journal, Fall:59-71.

Bourne, L \& Walker, DHT. 2005. Visualising and mapping stakeholder influence. Management Decision 43(5/6):649-660.

Bovey, WH \& Hede, A. 2001. Resistance to organizational change: The role of cognitive and affective processes. Leadership \& Organization Development Journal 22(8):372-382.

Buchanan, D \& Badham, R. 1999. Politics and organizational change: The lived experience. Human Relations 52:609-629.

Burke, R. 2007. Introduction to project management. Everbest, HK/China: Burke.

Burke, WW. 2008. A contemporary view of organization development. In: TG Cummings ed. Handbook of Organization Development. Thousand Oaks: Sage: 13-38.

Chermack, K. 2012. Engaging the dialectic: Managerial resistance to change and innovation in corporate America. Unpublished PhD, University of Minnesota.

Cummings, TG \& Worley, CG. 2015. Organization development and change. Stamford: Cengage Learning.

De Bussy, NM \& Kelly, L. 2010. Stakeholders, politics and power. Towards an understanding of stakeholder identification and salience in government. Journal of Communication Management 14(4):289-305.

Freeman, RE. 1984. Strategic management: A stakeholder approach. Boston: Pitman.

Freeman, RE \& McVea, J. 2001. A stakeholder approach to strategic management. In: M Hitt, J Harrison \& RE Freeman eds. Handbook of strategic management. Oxford: Blackwell:189-207.

French, JRP \& Raven, B. 1959. The bases of social power. In: Cartwright, D \& Zander, AF. eds. Group dynamics. Evanston, IL: Row, Petersen \& Co:259-269.

Giangreco, A \& Peccei, R. 2005. The nature and antecedents of middle manager resistance to change: Evidence from an Italian context. The International Journal of Human Resource Management 16 (10):1812.

Greenwood, M \& Van Buren, HJ. 2010. Trust and stakeholder theory: Trustworthiness in the organisation-stakeholder relationship. Journal of Business Ethics 95: 425-438.

Greiner, LE \& Schein, VE. 1988. Power and organization development: Mobilizing power to implement change. Reading, Massachusetts: Addison-Wesley.

Gubrium, JF \& Holstein, JA. 2001. In-depth interviewing. Handbook of interview research. SAGE Research Methods. Available at: doi:10.4135/9781412973588:104. 
Gupta, B \& Sharma, NK. 2008. Compliance with bases of power and subordinates' perception of superiors: Moderating effect of quality of interaction. Singapore Management Review 30(1):1-24.

Heifetz, RA \& Linsky, M. 2002. Leadership on the line: Staying alive through the dangers of leading: Boston: Harvard University Press.

Hultman, K. 1995. Scaling the wall of resistance. Training and Development Journal 49(10):15-22.

IBM. 2011. IBM SPSS exact tests. Available at: http://www-03.ibm.com/software/ products/us/en/spss-exact-tests/ (accessed on 10 August 2013).

Ireland, RD, Hoskisson, RE \& Hitt, MA. 2013. The management of strategy. Stamford, Connecticut: Cengage Learning.

Kanter, RM. 1980. Power failure in management circuits. The McKinsey Quarterly, Summer:68-87.

Klonek, FE, Lehmann-Willenbrock, N \& Kauffeld, S. 2014. Dynamics of resistance to change: A sequential analysis of change agents in action. Journal of Change Management 14(3):334-360.

Kotter, JP \& Schlesinger, LA. 2008. Choosing strategies for change. Harvard Business Review, Jul-Aug:130-139.

Kuhn, T. 2008. A communicative theory of the firm: Developing an alternative perspective on intra-organisational power and stakeholder relationships. Organization Studies 29(08\&09):1227-1254.

Lewin, K. 1951. Field theory in social science: Selected theoretical papers. New York: Harper.

Lichtenstein, BB, Uhl-Bien, M, Marion, R, Seers, A, Douglas, J \& Schreiber, C. 2006. Complexity leadership theory: An interactive perspective on leading in complex adaptive systems, Emergence: Complexity \& Organisation 8(4):2-12.

Mehta, CR \& Patel, NR. 2011. IBM SPSS exact tests. Available at: ftp://public.dhe.ibm. com/software/analytics/spss/documentation/statistics/20.0/en/client/Manuals/IBM_S PSS_Exact_Tests.pdf (accessed on 20 August 2013).

Mitchell, RK, Agle, BR \& Wood, DJ. 1997. Toward a theory of stakeholder identification and salience: Defining the principle of who and what really counts. The Academy of Management Review 22(4):853-886.

Newcombe, R. 2010. From client to project stakeholders: A stakeholder mapping approach. Construction Management and Economics 21(8):841-848.

Olander, S \& Landin, A. 2005. Evaluation of stakeholder influence in the implementation of construction projects, Journal of Project Management 23: 321-328.

Oreg, S. 2006. Personality, context, and resistance to organizational change. European Journal of Work and Organizational Psychology 15(1):73-101.

Pfeffer, J. 1992. Understanding power in organizations. California Management Review 34(2):29-50.

Piderit, SK. 2000. Rethinking resistance and recognizing ambivalence: $A$ multidimensional view of attitudes toward an organizational change. Academy of Management Review 25(4):783-794. 
Rashid, A. 2015. The influence of stakeholder power on corporate social responsibility: Evidence from a relationship-based economy. Social Responsibility Journal 11(2):270-289.

Raven, BH. 2008. The bases of power and the power/interaction model of interpersonal influence. Analyses of Social Issues \& Public Policy 8(1):1-22.

Reed, M. 2008. Stakeholder participation for environmental management: A literature review. Biological Conservation doi:10.10.16.

Rigby, R \& Bilodeau, B. 2015. Management tools and trends 2015. Boston: Bain:1-19.

Robbins, SP, Judge, TA, Odendaal, A \& Roodt, G. 2009. Organisational behaviour: Global and South African perspectives. $2^{\text {nd }}$ ed. Cape Town, South Africa: Pearson Education South Africa.

Saunders, M \& Lewis, P. 2012. Doing research in business and management: An essential guide to planning your project. Edinburgh Gate, Harlow, England: Pearson Education.

Schein, E. 2010. The long view. Training \& Development (T \& D), December:67.

Smollan, RK. 2011. The multi-dimensional nature of resistance to change. Journal of Management \& Organization 17(6):828-849.

Summers, JK, Humphrey, SE \& Ferris, GR. 2012. Team member change, flux in coordination, and performance: Effects of strategic core roles, information transfer, and cognitive ability. Academy of Management Journal 55:314-338.

Thomas, R \& Hardy, C. 2011. Reframing resistance to organisational change. Scandinavian Journal of Management 27:322-331.

Trader-Leigh, KE. 2002. Case study: Identifying resistance in managing change. Journal of Organizational Change Management 15(2):138-155.

Uhl-Bien, M \& Marion, R. 2009. Complexity leadership in bureaucratic forms of organizing: A meso model. The Leadership Quarterly 20:631-650.

Weiers, R. 2011. Introductory business statistics. $7^{\text {th }}$ ed. South Western Cengage Learning.

Willer, D, Lovaglia, MJ \& Markovsky, B. 1997. Power and influence: A theoretical bridge. Social Forces 76(2):571-603.

Zikmund, WG, Babin, BJ, Carr, JC \& Griffin, M. 2013. Business research methods. Mason, $\mathrm{OH}$ : Cengage. 